\title{
Study of reinforced elastomeric bearings for structures in seismic areas
}

\author{
Larisa Safina ${ }^{1, *}$, Aleksandr Shuvalov $^{1}$ and Mikhail Kovalev ${ }^{1}$ \\ ${ }^{1}$ Moscow State University of Civil Engineering, Yaroslavskoe shosse, 26, Moscow, 129337, Russia
}

\begin{abstract}
The article presents the results of the experimental determination of the physical and mechanical characteristics of rubber-metal vibrationproof supports used in the construction of facilities in the areas of increased seismic hazard. The testing was based on two necessities: to substantiate the possibility of using such a constructive seismic protection solution and to create reliable calculation models of the structures with rubber-metal support. More than thirty samples were tested in the laboratory under various loads and impacts. The elastomers were tested in accordance with the requirements written in EN-1337-3. The experiment was performed on three types of elastomer model samples to determine their vertical and horizontal stiffness, the tensile strength and modulus of elasticity and creep. The work was performed on INSTRON power equipment and a test rig equipped with MTS hydraulic jacks installed in the power frame. The testing results of elastomeric support models were confirmed by the determination of individual characteristics on the full size specimens at the corresponding load. Thus, the test has confirmed and proved the validity of the use of elastomeric bearings for seismic protection of a mall construction.
\end{abstract}

\section{Introduction}

During the construction of the facilities in seismic regions, there is a variety of special methods used to ensure the seismic. Seismic isolation system is one of them.

In the "Construction in seismic regions" Code of Regulations it is stated that the reduction of seismic loads on the construction is possible due to the use of special structural elements [1] that:

- increase the flexibility and periods of natural oscillations of the structure (flexible supports, rocking supports, metal-rubber bearings, etc.) $[2,10]$.

- increase the absorption (dissipation) of the energy of seismic oscillations (dry friction dampers, sliding belts, hysteresis, viscous dampers);

- are backup switch-off elements [3].

Moreover, seismic protection can be designed using one or more of the listed elements or their combinations: insulators, damping devices, wind load resistance devices, devices for limiting movement [4].

${ }^{*}$ Corresponding author: $\underline{\text { mgsu_pgs_safinal@,mail.ru }}$ 
According to the project for the building of the "Gornaya Karusel" mall in Sochi the metal structures of the coating on the reinforced concrete structures of the facility were supported with rubber-metal vibration isolators that are called elastomeric bearings [9] or elastomeric supports. However, the possibility of using such constructive seismic protection solution was in question due to the lack of domestic regulatory documents.

The regulatory documents of other countries (EN 1337-3 [5], AASHTO LRFD Bridge Design Specifications 2012 [6], ISO 22762-1 [7]) were studied in order to validate the possibility of using elastomeric bearings on this facility. Based on these documents with the existence of separating forces in the structural system the use of such elastomers was either limited to the ultimate horizontal displacements or even banned altogether.

In the light of the circumstances mentioned above in order to ensure the required level of seismic protection of the building and create reliable design models of the structure with support for rubber-metal supports, it was necessary to use experimental method to determine the actual physical and mechanical characteristics of elastomers proposed for use during the project. During the testing, it was required to determine the values of all the characteristics needed to confirm the possibility of using elastomers of this design.

\section{Materials and methods}

The elastomers were tested in accordance with the program described in EN 1337-3 [5, 9].

Prior to the tests and taking into account the lack of a technical specification data for the elastomers used, a preliminary theoretical assessment of the load-bearing capacity of the building was carried out. In particular, the coating structures were tested for the criteria of stability, strength and ultimate displacements. Also, the assesment of the degree of influence of the possible nonlinear deformation of the design model was taken. Thus, we defined the values and nature of loads and effects on elastomeric supports that were realized during the experiment.

The samples of rubber-metal vibration isolators, as well as their models, were tested. Figure 1 shows the composition and geometric dimensions of the tested elements. The testing of full-scale specimens of elastomeric supports with the overall dimensions of 1100x1000x133 mm was carried out under the supervision of MIDDLE EAST TECHNICAL UNIVERSITY Civil Engineering Department (Ankara, Turkey) [8], commissioned by Esta Construction LLC, the organization that designed and built the facility. The experiment was carried out in accordance with the test procedure presented in EN 1337-3: 2005 (E) Annex F.

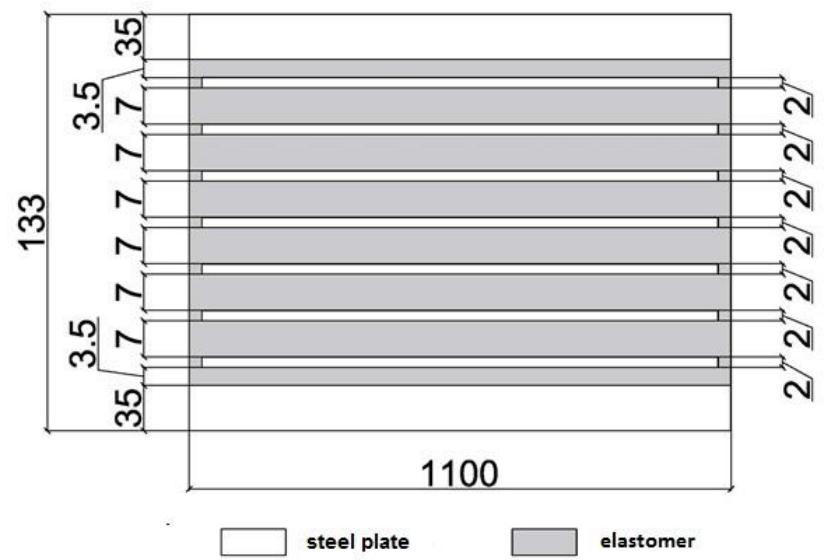

Fig. 1. Scheme of the full-scale sample of elastomeric supports. 
According to the results of tests of three samples, according to the formula (1) and taking into account the shear modulus and elastomer geometry, there was defined the average value of horizontal stiffness of the samples equal to $\mathrm{Kh}=21.98 \mathrm{t} / \mathrm{cm}$, which exceeds the minimum permissible value $\mathrm{Kh} \min =20 \mathrm{t} / \mathrm{cm}$ in accordance with the requirements of EN 1337-3.

$$
\mathrm{Kh}=\mathrm{G} \cdot \mathrm{A} / \mathrm{Tr}
$$

Where: $\mathrm{G}$ is the shear modulus, $\mathrm{A}$ is the area of the sample, $\mathrm{Tr}$ is the total thickness of the rubber layers in the sample.

Tests of the elastomer models were carried out in the test laboratory for the building structures of the "Testing of Structures" scientific and educational center at the Moscow State University of Civil Engineering (Moscow, Russia).

During the tests there were determined:

1. The horizontal stiffness of $\mathrm{Kh}$ and the modulus of deformation $\mathrm{G}$ under horizontal load:

- in the initial state;

- after 3 cycles of loading with displacement $\Delta \mathrm{h}= \pm 30 \mathrm{~mm}$, equivalent to displacement under temperature influence;

- after 3 cycles of loading with displacement $\Delta \mathrm{h}= \pm 40 \mathrm{~mm}$, equivalent to displacement during seismic load;

- after cyclic tests (400 loading cycles) with displacement $\Delta \mathrm{h}= \pm 30 \mathrm{~mm}$;

- after exposure to low temperatures of $-18{ }^{\circ} \mathrm{C}$ and $-25^{\circ} \mathrm{C}$;

- after ageing.

2. In the compression test:

- vertical stiffness $\mathrm{Kv}$;

- reduced elasticity modulus of the elastomeric bearing E;

- modulus of elasticity of rubber elastomer Ep in the initial state and after holding under the load for 5 minutes

3. Tensile strength, shear strength, modulus of elastomer rubber under horizontal load

4. Creep tests.

The work was carried out on INSTRON power equipment and a test rig equipped with MTS hydraulic jacks installed in the power frame. Three types of elastomer samples were tested.

Previously, the initial geometric characteristics of these samples were determined. The geometric dimensions of the models of elastomeric supports were assigned depending on the type of stress-strain state that arose in the sample during the test loading and simulated the real work of the full-scale element.

The tests to determine horizontal stiffness; changes in horizontal stiffness after cyclic horizontal displacement, equivalent to seismic and temperature effects; determination of vertical stiffness and modulus of elasticity under vertical load; changes in the properties of elastomers exposed to a negative temperature (at a temperature of $\mathrm{t}=-25^{\circ} \mathrm{C}$ for 7 days) and ageing (three days at a temperature of $\mathrm{t}=+70^{\circ} \mathrm{C}$ ) were carried out on samples with dimensions of $275 \times 250 \times 133 \mathrm{~mm}$. The test schemes are shown in Figures 2.a and 2.b.

Samples with dimensions of $275 \times 250 \times 133 \mathrm{~mm}$ represent a model of the full-scale element with a scale of 1:16 in area, having a full-scale size in thickness. The test loads were assigned considering the ratio of the design load, the type of loading and the geometric characteristics of each sample model.

These types of tests were carried out at a temperature of $23^{\circ} \mathrm{C} \pm 2^{\circ} \mathrm{C}$, using the following equipment and auxiliary devices:

- Test rig with hydraulic cylinders of MTS, installed in the power frame;

- INSTRON 1000HDX testing machine with load measurement error less than $\pm 0.5 \%$;

- Electronic displacement indicators with a $0.01 \mathrm{~mm}$ division and a measurement range from 0 to $50 \mathrm{~mm}$. 

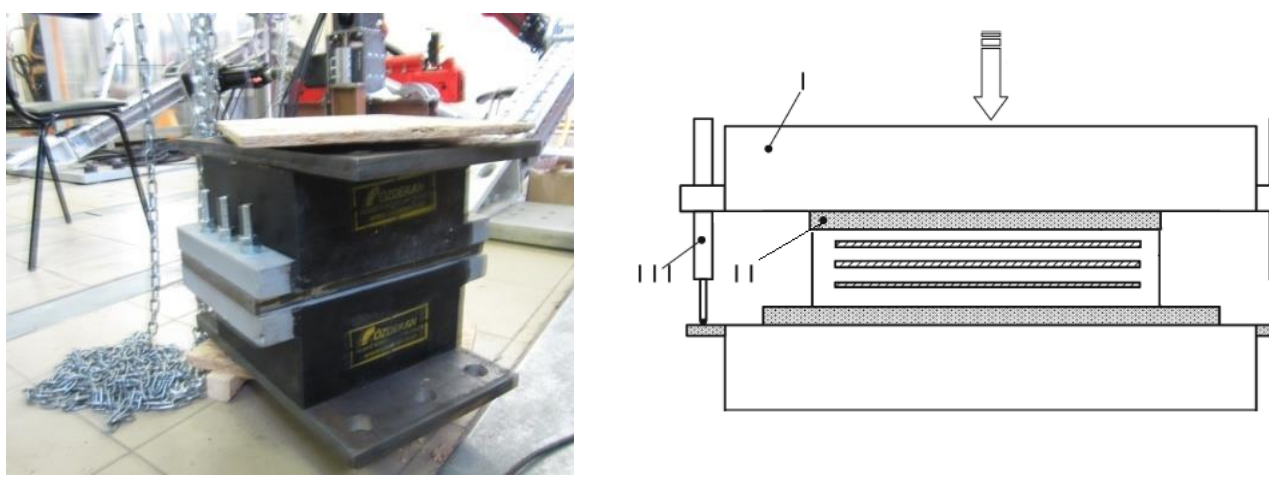

Fig. 2.a. A sample for testing elastomers for vertical load.

A visual inspection was performed to detect the errors during the tests such as rubber cracks on the side surfaces of the samples; "bridges" of rubber, combining adjacent rollers; general flexure of the side surfaces of the sample; local elevations of squeezed rubber.

The tests to determine the tensile strength of joints of elastomeric bearing parts and tensile modulus were carried out on sample models with dimensions of 100x100x133 mm; the definition of creep was carried out on rubber samples measuring 51x51x36 mm.
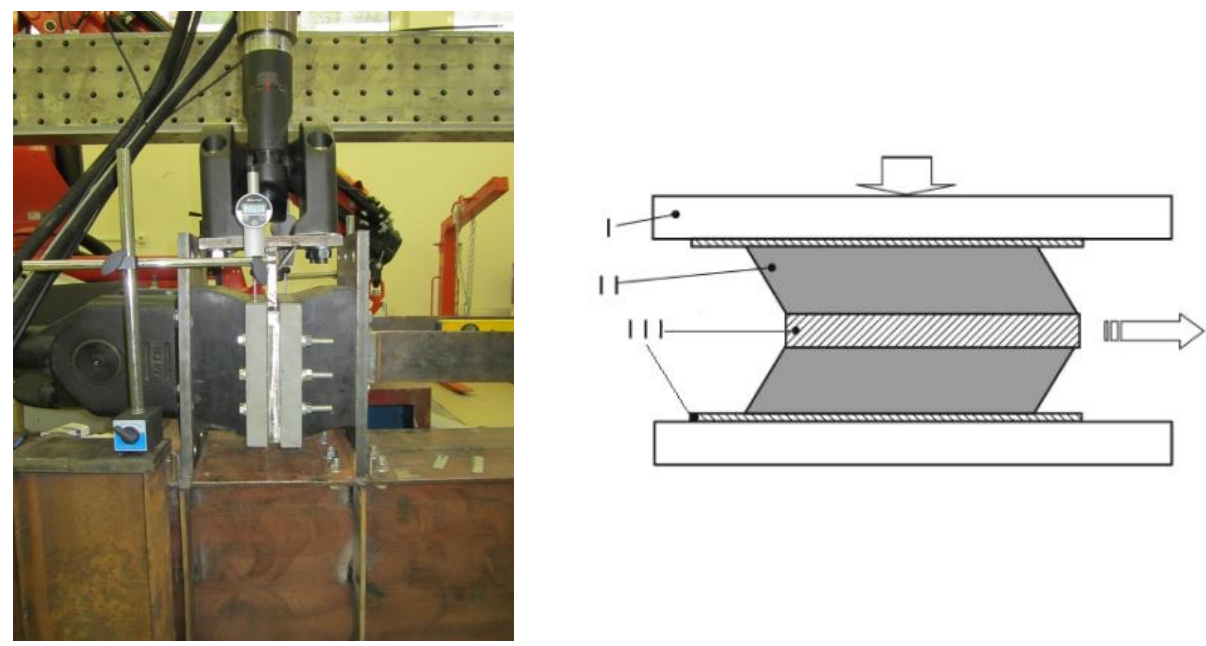

Fig. 2.b. A sample for testing elastomer for horizontal load. I - press plates, II - test specimen, III steel plates.

Tables 1.a and 1.b show the types of tests, the dimensions of the tested samples and the test equipment required to obtain the actual characteristics of elastomeric bearings for various types of loads and impacts. 
Table 1.a. Types of tests, dimensions of tested samples and characteristics of testing equipment.

\begin{tabular}{|c|c|c|c|c|c|}
\hline \multirow{3}{*}{$\begin{array}{l}\text { Characteristic } \\
\text { of elastomer }\end{array}$} & \multicolumn{5}{|c|}{ Type of test, loading conditions } \\
\hline & \multicolumn{2}{|c|}{ Cyclic tests with displacement } & \multirow{2}{*}{$\begin{array}{l}\text { Cyclic } \\
\text { testing } \\
(400 \\
\text { cycles })\end{array}$} & \multirow{2}{*}{$\begin{array}{c}\text { Testing } \\
\text { under the } \\
\text { influence of } \\
\text { low } \\
\text { temperatures }\end{array}$} & \multirow[b]{2}{*}{$\begin{array}{l}\text { Tests for } \\
\text { "ageing" }\end{array}$} \\
\hline & $\begin{array}{l}\text { Equivalent to } \\
\text { temperature } \\
\text { effects }\end{array}$ & $\begin{array}{l}\text { Equivalent to } \\
\text { seismic action }\end{array}$ & & & \\
\hline $\begin{array}{l}\text { Horizontal } \\
\text { stiffness } \\
\mathrm{Kh}, \mathrm{t} / \mathrm{cm}\end{array}$ & \multirow{2}{*}{\multicolumn{5}{|c|}{$\begin{array}{l}\qquad 275 \times 250 \times 133 \mathrm{~mm} \\
\text { - Test rig with hydraulic cylinders of MTS, installed in the power frame; } \\
\text { - Electronic displacement indicators with a } 0.01 \mathrm{~mm} \text { division and a measuring } \\
\text { range from } 0 \text { to } 50 \mathrm{~mm} \text {. }\end{array}$}} \\
\hline $\begin{array}{l}\text { Modulus } \\
\text { under } \\
\text { horizontal } \\
\text { load G, MPa }\end{array}$ & & & & & \\
\hline
\end{tabular}

Table 1.b. Types of tests, dimensions of tested samples and characteristics of testing equipment.

\begin{tabular}{|c|c|c|c|c|}
\hline \multirow[b]{2}{*}{$\begin{array}{c}\text { Characteristic } \\
\text { of } \\
\text { elastomer }\end{array}$} & \multicolumn{4}{|c|}{ Type of test, nature of loading } \\
\hline & $\begin{array}{l}\text { Compression tests } \\
\text { with an exposure } \\
\text { time of } 5 \mathrm{~min}\end{array}$ & Tensile tests & Creep tests & $\begin{array}{l}\text { Determination } \\
\text { of shear } \\
\text { strength } \\
\text { (after the } \\
\text { creep test) }\end{array}$ \\
\hline $\begin{array}{l}\text { Vertical } \\
\text { stiffness } \\
\text { Kv, } / \text { cm }\end{array}$ & \multirow{2}{*}{$\begin{array}{l}275 \times 250 \times 133 \mathrm{~mm} \\
\text { INSTRON } \\
\text { 1000HDX testing } \\
\text { machine with load } \\
\text { measurement error } \\
\text { less than } \pm 0.5 \% \text {; } \\
\text { Electronic } \\
\text { displacement } \\
\text { indicators with a } \\
\text { division of } 0.01 \mathrm{~mm} \\
\text { and a measurement } \\
\text { range from } 0 \text { to } 50 \\
\text { mm; }\end{array}$} & \multirow{3}{*}{----------- } & \multirow{5}{*}{$\begin{array}{c}51 \times 51 \times 36 \\
\text { mm } \\
\text { INSTRON } \\
8802 \\
\text { hydraulic } \\
\text { machine with } \\
\text { error of load } \\
\text { measurement } \\
\pm 0.5 \% \text {. }\end{array}$} & \multirow{5}{*}{$\begin{array}{l}51 \times 51 \times 36 \\
\text { mm } \\
\text { INSTRON } \\
3382\end{array}$} \\
\hline $\begin{array}{l}\text { Reduced } \\
\text { elastic } \\
\text { modulus E, } \\
\text { MPa }\end{array}$ & & & & \\
\hline $\begin{array}{l}\text { Modulus of } \\
\text { elastomer } \\
\text { rubber } \\
\mathrm{E}_{\mathrm{p} .}, \mathrm{MPa} \\
\end{array}$ & \multirow{3}{*}{------------ } & & & \\
\hline $\begin{array}{c}\text { Initial } \\
\text { modulus of } \\
\text { elasticity, } \\
\text { Ep.H, MPa } \\
\end{array}$ & & $\begin{array}{l}\text { 100x100x133 mm } \\
\text { INSTRON } 1000 \mathrm{HDX} \\
\text { testing machine with } \\
\text { load measurement }\end{array}$ & & \\
\hline $\begin{array}{l}\text { Tensile } \\
\text { strength, } \\
\mathrm{R}_{\mathrm{p} .,} \mathrm{MPa}\end{array}$ & & $\begin{array}{l}\text { error less than } \pm 0.5 \% \text {; } \\
\text { Electronic } \\
\text { displacement } \\
\text { indicators with a } \\
\text { division of } 0.01 \mathrm{~mm} \\
\text { and a measurement } \\
\text { range from } 0 \text { to } 50 \\
\mathrm{~mm} ;\end{array}$ & & \\
\hline
\end{tabular}




\section{Test results}

The physical and mechanical properties of elastomers obtained as a result of the tests are presented in Tables 2.a and 2.b.

Table 2.a. Physical and mechanical characteristics of elastomers under different loads and impacts.

\begin{tabular}{|c|c|c|c|c|c|c|c|c|c|c|c|c|c|c|c|c|c|c|c|c|}
\hline \multirow{3}{*}{ 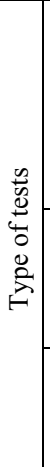 } & \multicolumn{4}{|c|}{$\begin{array}{l}\text { Cyclic loading } \pm \\
30 \mathrm{~mm}, \\
\text { equivalent to } \\
\text { displacement at } \\
\text { temperature } \\
\text { exposure }\end{array}$} & \multicolumn{4}{|c|}{$\begin{array}{c}\text { Cyclic loading } \pm \\
40 \mathrm{~mm} \text {, equivalent } \\
\text { to displacement } \\
\text { during seismic } \\
\text { load }\end{array}$} & \multicolumn{4}{|c|}{$\begin{array}{l}\text { Cyclic test (400 } \\
\text { cycles) with an } \\
\text { displacement of } \pm \\
\quad 30 \mathrm{~mm}\end{array}$} & \multicolumn{4}{|c|}{$\begin{array}{l}\text { The effect of low } \\
\text { temperatures } \\
-18^{\circ} \mathrm{C} /-25^{\circ} \mathrm{C}\end{array}$} & \multicolumn{4}{|c|}{ Ageing } \\
\hline & \multicolumn{2}{|c|}{ Initial } & \multicolumn{2}{|c|}{$\begin{array}{c}\text { After } \\
\text { testing } \\
\text { operati } \\
\text { ons } \\
\end{array}$} & \multicolumn{2}{|c|}{ Initial } & \multicolumn{2}{|c|}{$\begin{array}{l}\text { After } \\
\text { testing } \\
\text { operati } \\
\text { ons } \\
\end{array}$} & \multicolumn{2}{|c|}{ Initial } & \multicolumn{2}{|c|}{$\begin{array}{c}\text { After } \\
\text { testing } \\
\text { operati } \\
\text { ons } \\
\end{array}$} & \multicolumn{2}{|c|}{ Initial } & \multicolumn{2}{|c|}{$\begin{array}{l}\text { After } \\
\text { exposu } \\
\text { re }\end{array}$} & \multicolumn{2}{|c|}{ Initial } & \multicolumn{2}{|c|}{$\begin{array}{c}\text { After } \\
\text { ageing }\end{array}$} \\
\hline & 导 & $\stackrel{8}{8}$ & $\stackrel{P}{I}$ & i & 早 & $\stackrel{8}{8}$ & $\stackrel{8}{i 1}$ & II & 早 & $\begin{array}{l}8 \\
\stackrel{1}{4}\end{array}$ & $\stackrel{?}{\stackrel{9}{I}}$ & II & 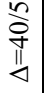 & II & $\stackrel{8}{\text { II }}$ & $\stackrel{8}{8}$ & 早 & II & $\stackrel{?}{\stackrel{+}{4}}$ & $\stackrel{8}{8}$ \\
\hline 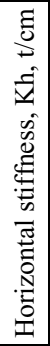 & $\stackrel{m}{\longrightarrow}$ & $\stackrel{g}{\stackrel{g}{-}}$ & $\stackrel{\oplus}{\oplus}$ & ભે & $\stackrel{\text { f̊ }}{-}$ & $\stackrel{n}{q}$ & సે & $\stackrel{\sim}{\dddot{q}}$ & ֶิ & $\stackrel{+}{\stackrel{+}{*}}$ & $\stackrel{\overbrace{}}{\cong}$ & సે & 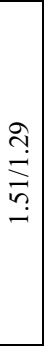 & 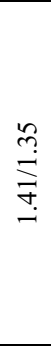 & 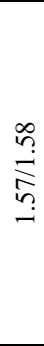 & 禜 & $\stackrel{n}{\longrightarrow}$ & $\stackrel{n}{\rightarrow}$ & $\stackrel{n}{m}$ & $\stackrel{\infty}{\stackrel{\infty}{-}}$ \\
\hline 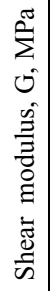 & $\stackrel{\infty}{\circ}$ & $\stackrel{8}{.}$ & $\stackrel{0}{\circ}$ & ڤे & $\underset{\text {. }}{.}$ & $\underset{-}{\stackrel{0}{-}}$ & ô & à & $\stackrel{\infty}{\stackrel{\infty}{\leftrightarrow}}$ & $\stackrel{\beta}{\beta}$ & $\stackrel{8}{\circ}$ & ô. & 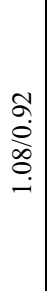 & $\begin{array}{l}\hat{a} \\
\stackrel{0}{0} \\
\stackrel{0}{-}\end{array}$ & 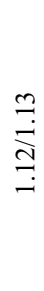 & 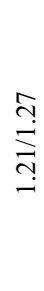 & $\stackrel{\infty}{\stackrel{0}{\circ}}$ & $\stackrel{s}{.}$ & $\stackrel{2}{\circ}$ & $\stackrel{n}{2}$ \\
\hline
\end{tabular}

Table 2.b. Physical and mechanical characteristics of elastomers under different loads and impacts.

\begin{tabular}{|c|c|c|c|c|c|c|c|c|}
\hline \multirow{3}{*}{ Type of tests } & \multicolumn{2}{|c|}{$\begin{array}{l}\text { Compression test } \\
\text { with an exposure } \\
\text { time of } 5 \text { minutes }\end{array}$} & \multirow{3}{*}{ Tension } & \multicolumn{3}{|c|}{ Creep, \% } & \multirow{3}{*}{$\begin{array}{c}\text { Shear } \\
\text { strength } \\
\mathrm{Rs}, \\
\mathrm{MPa}\end{array}$} & \multirow{3}{*}{$\begin{array}{c}\text { Shear } \\
\text { modulus } \\
\text { of } \\
\text { elastomer } \\
\text { rubber } \\
\mathrm{G}, \mathrm{MPa}\end{array}$} \\
\hline & \multirow[b]{2}{*}{ Initial } & \multirow{2}{*}{$\begin{array}{c}\text { After } \\
\text { testing } \\
\text { operations }\end{array}$} & & \multicolumn{3}{|c|}{ Time } & & \\
\hline & & & & $\begin{array}{c}1 \\
\text { hour }\end{array}$ & $\begin{array}{c}25 \\
\text { years }\end{array}$ & $\begin{array}{c}50 \\
\text { years }\end{array}$ & & \\
\hline $\begin{array}{c}\text { Vertical } \\
\text { stiffness } \\
\mathrm{Kv}, \mathrm{t} / \mathrm{cm}\end{array}$ & 1049.00 & 1107.00 & & \multirow[b]{2}{*}{0.00} & \multirow[b]{2}{*}{20.03} & \multirow[b]{2}{*}{21.17} & \multirow[b]{2}{*}{8.93} & \multirow[b]{2}{*}{0.85} \\
\hline $\begin{array}{c}\text { Reduced } \\
\text { elastic } \\
\text { modulus } \\
\text { E, MPa }\end{array}$ & 960.00 & 1014.00 & & & & & & \\
\hline
\end{tabular}




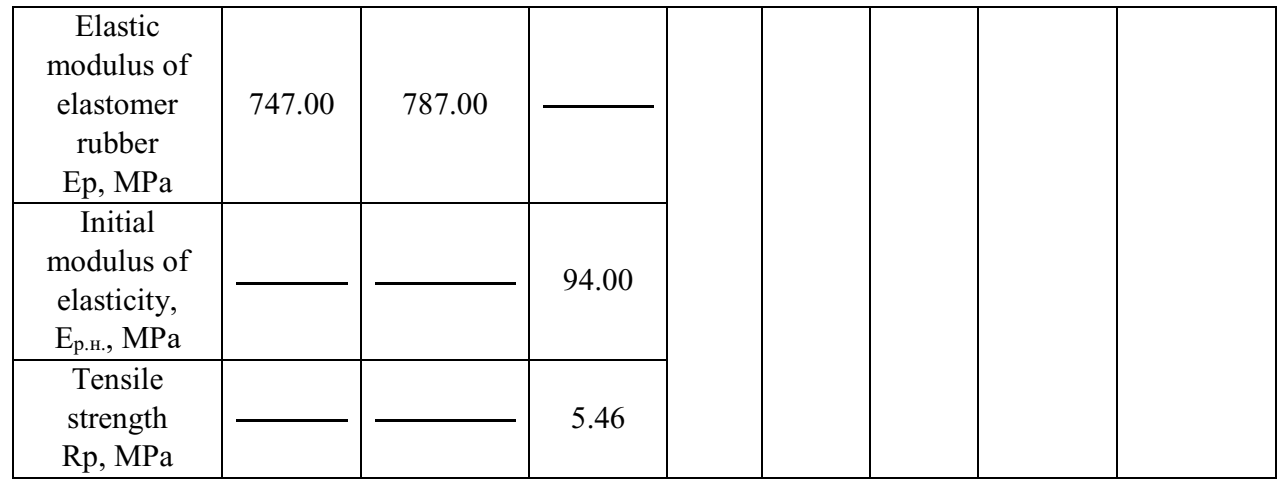

\section{Results analysis}

The analysis of the test results of the sample models presented in Tables 2.a and 2.b has shown the following:

- The characteristics of elastomeric bearings obtained by testing their models and the results of field tests carried out by colleagues led by Civil Engineering Department METU (Ankara, Turkey) have good convergence (discrepancy within $1.9 \%$ );

- Initial horizontal stiffness is above the minimum allowed $\mathrm{Kh}=1.25 \mathrm{t} / \mathrm{cm}$ in accordance with the requirements of EN 1337-3

- The horizontal stiffness of elastomers after loading decreased in comparison with the original one by no more than $10.4 \%$ with the exception of the effect of low temperatures where an increase in horizontal stiffness by $32 \%$ was noted.

- The horizontal stiffness values after the tests in all cases were not lower than the minimum allowed $\mathrm{Kh}=1.25 \mathrm{t} / \mathrm{cm}$.

- In tensile tests failure occurred in rubber; the tensile strength was two orders of magnitude greater than the design tensile stresses.

- The vertical stiffness of the elastomer both in the initial state and after compression under the load was above the minimum allowable value of $\mathrm{Kv}=640 \mathrm{t} / \mathrm{cm}$ by an average of $68 \%$.

\section{Conclusions}

As a result of the tests it has been established that the values of all the characteristics used in the design model of the building with supports of rubber-metal bearings are within the limits permitted by EN 1337-3: 2005. The legitimacy of using elastomeric bearings of this design for seismic protection of the building of the mall that was offered in the project has been experimentally confirmed.

\section{References}

1. Russian Standard SP 14.13330.2014

2. A.R. Arutyunyan, Inzhenerno-stroitel'nyy zhurnal 3, 56-60 (2010)

3. V.I. Smirnov, Seysmostoykoe stroitel'stvo. Bezopasnost' sooruzheniy 4, 41-54 (2013)

4. E.V. Litvinova, B.A. Litvinov, Stroitel'stvo i tekhnogennaya bezopasnost' 47, 69-78 (2013)

5. European Standard EN 1337-3:2005 
6. AASHTO LRFD Bridge Design Specifications, Customary U.S. Units, 7th edition

7. International Standard ISO 22762-1:2010

8. Technical report on full-scale tests (Middle East Technical University Civil Engineering Department, Ankara)

9. L. Nittmannová, M. Magura, Procedia Engineering 156, 280-287 (2016)

10. Govardhan, D.K. Paul, R. Jain, S.N Bagchi, Bearings and Seismic systems (2011) 